Disponível em:

http://editora.unoesc.edu.br/index.php/race

Race, Joaçaba, v. 15, n. 2, p. 395-418, maio/ago. 2016

\title{
REGIONAL ANALYSIS BASED ON THE DEMOGRAPHIC AND ECONOMIC VARIATION OF THE ASSOCIATION OF THE MUNICIPALITIES OF WESTERN SANTA CATARINA
}

Análise regional com base na variação demográfica e econômica da associação dos municípios do Oeste de Santa Catarina

\begin{abstract}
Rógis Juarez Bernardy
E-mail: rjbernardy@gmail.com

Doctor in Civil Engineering in the area of Multipurpose Technical Register and Territorial Management by Universidade Federal de Santa Catarina; Post-doctorate in the Post-graduate Program in Regional Development of Universidade de Santa Cruz do Sul; Professor of Universidade do Oeste de Santa Catarina; Coordinator and member of the permanent academic staff of the Professional Masters in Administration. Contact address: Avenida Getúlio Vargas, 2125, Flor da Serra, 89600-000, Joaçaba, Santa Catarina, Brasil.

Erica Karnopp

E-mail: erica@unisc.br

Doctor in Geography by Universität Tübingen, Germany (Eberhand-Karls Universität); Master in Rural Extension by Universidade Federal de Santa Maria; Professor of the Geography Course in Universidade de Santa Cruz do Sul; Researcher and Professor of the Post-graduate Program in Regional Development of Universidade de Santa Cruz do Sul.

\section{Virgínia Elisabeta Etges}

E-mail: etges@unisc.br

Post-doctor in Urban and Regional Planning by Universidade Técnica de Berlim;

Doctor in Human Geography by Pontifícia Universidade Católica de São Paulo; Professor of the Geography Course in Universidade de Santa Cruz do Sul; Professor of the Post-graduate Program in Regional Development of Universidade de Santa Cruz do Sul.

Olgário Paulo Vogt E-mail: olgario@unisc.br Doctor in Regional Development by Universidade de Santa Cruz do Sul; Master in Brazilian History by Universidade Federal do Paraná; Professor of History of the Department of History and Geography of Universidade de Santa Cruz do Sul; Professor of the Post-graduate Program in Regional Development of Universidade de




\begin{abstract}
The researches that address the socioeconomic variables in different regions have been used in various knowledge fields, once they permit detailed regional analysis, in this case, of demographic and economic indicators. These studies are relevant in geographic scopes, both nationals and states or regionals, due to the significant spatial differences in terms of mobility and economic diversification with different levels of specialization, not always associated to geophysical factors. In this sense, the main aim with this research was to analyze the characteristics of the demographic and socioeconomic dynamic of Associação dos Municípios do Oeste de Santa Catarina (AMOSC) [Association of the Municipalities of Western Santa Catarina]. The methodological process envisaged two groups of quantitative variables: the demographic evolution and variation and the evolution of the economic aggregates, thus, the focus is quantitative. As a result, it was observed an increase of asymmetries among the municipalities of the region, since there is a population, work and income concentration. It was also observed the reduction of the dynamism of the economic activities, in consequence of structural factors, which influence the relocation of industrial facilities to other regions of the country. The region studied resents the loss of competitiveness due to the dependence of inputs to the livestock flocks that sustain the agribusiness, as well as in consequence of the precariousness of regional roadways, and of the distance of the ports and the consumer markets.
\end{abstract}

Keywords: Regional development. Regional asymmetries. Socioeconomic dynamic.

\title{
Resumo
}

As pesquisas que aportam as variáveis socioeconômicas nas distintas regiões têm sido utilizadas nos mais diversos campos de conhecimento, uma vez que permitem análises regionais detalhadas, neste caso, de indicadores demográficos e econômicos. Estes estudos são relevantes em âmbitos geográficos, tanto nacionais quanto estaduais ou regionais, em razão das expressivas diferenças espaciais em termos de mobilidade e diversificação econômica com distintos níveis de especialização, nem sempre associadas aos fatores geofísicos. Nesse sentido, com esta pesquisa teve-se como objetivo principal analisar as características da dinâmica demográfica e socioeconômica da Associação dos Municípios do Oeste de Santa Catarina (AMOSC). O processo metodológico contemplou dois grupos de variáveis quantitativas: a evolução e variação demográfica e a evolução dos agregados econômicos, portanto, o enfoque é quantitativo. Como resultados, observou-se um aumento das assimetrias entre os municípios da região, pois existe uma concentração populacional, de trabalho e de renda. Também se observou a redução do dinamismo das atividades econômicas, em razão de fatores estruturais, que influenciam o deslocamento de plantas industriais para outras regiões do País. A região estudada ressentese da perda de competitividade em decorrência da dependência de insumos para os plantéis pecuários que sustentam a agroindústria, bem como em decorrência da precariedade das vias rodoviárias regionais e das distâncias dos portos e dos mercados consumidores.

Palavras-chave: Desenvolvimento regional. Assimetrias regionais. Dinâmica socioeconômica. 


\section{INTRODUCTION}

Researches on demographic dynamics linked to the economic factors are interesting to get to know the reality of a region, once the areas with population decline are normally devoid of activities able to provide an adequate work and income condition, thus, they imply the local population's life quality and prospects. In this context, in this research the main aim is to analyze the characteristics of the demographic and economic dynamics of the Associação dos Municípios do Oeste de Santa Catarina (AMOSC) [Association of the Municipalities of Western Santa Catarina], composed by twenty municipalities, all of them small (except Chapecó) and located in the West of Santa Catarina, Brazil.

This AMOSC's administrative regionalization derives from the 60s, from the twentieth century and comprehends the municipalities of Águas de Chapecó, Águas Frias, Caxambu do Sul, Chapecó, Cordilheira Alta, Coronel Freitas, Formosa do Sul, Guatambu, Irati, Jardinópolis, Nova Erechim, Nova Itaberaba, Pinhalzinho, Planalto Alegre, Quilombo, São Carlos, Santiago do Sul, Serra Alta, Sul Brasil and União do Oeste, all of them located in the Mesoregion West of Santa Catarina (ASSOCIAÇÃO DOS MUNICÍPIOS DO OESTE DE SANTA CATARINA, 2014).

The synthesis of the methodological process envisaged two great groups of quantitative variables: population evolution and variation from 1970 till 2010; demographic growth of the municipalities, from 1970 till 2010 and the evolution of the economic aggregates, such as the total and the per capita Gross Domestic Product (GDP) at current deflated prices and the Gross Added Values (GAV) at current deflated prices, of the agriculture and cattle raising, the industry and services and balance of jobs, total and by sector. For the purposes of this study, it was considered to the GDP the sum of all wealth (goods and services) produced in a given period, and to the GAVs, the monetary amounts of the production of the respective sectors in a given period, subtracted from the inputs used in the productive process (intermediate consume), in order to avoid double counting.

Among the main results of the research, in the demographic context, it is pointed out an uneven growth among the municipalities and the slowdown of their positive variation. The most populous municipalities, which, by coincidence, have more dynamic economies, have higher growth rates, while most of the municipalities with less than ten thousand inhabitants have negative growth rates. 
In the economic context, the behavior of the Gross Domestic Product (GDP) during the period analyzed was characterized by strong oscillations, tending to the growth decline. Sectorally, the variations of the Gross Added Values (GAVs) confirm the low performance of the agriculture and industry, the loss of competitiveness of the agricultural industries, and confirm the reasons for the worries with the tendency to economic depression of the region, to the coming periods.

This research is composed by this introductory section, by a bibliographical study on the territorial and regional sociospatial formation of Western Santa Catarina, by the methodological procedures, by the contextualization of the formation of AMOSC formation, its demographic variation and the evolution of the economic aggregates, by conclusion and, finally, by the references.

\section{TERRITORIAL AND REGIONAL SOCIOSPATIAL FORMATION}

The region of the Association of the Municipalities of Western Santa Catarina (AMOSC) had a more effective process of occupation since the "transplant" of immigrants descendants of Italians, Germans and Polishes, native, mainly, from Rio Grande do Sul, in areas of induced colonization (WERLANG, 2002). At the beginning of the twentieth century, the integration of this region to the regional and national territory took place, because of factors like geopolitical aspects by the intern dispute in Contestado War, the enlargement of the productive bases of the country and the "pressure for natural resources" in areas of ancient colonization, in Rio Grande do Sul. These factors provided a process of insertion of the region to the basis of capitalist production, although still partially, by the difficulties of communication and production flow paths (KONRAD; DA SILVA, 2012).

This way, this environment that became integrated, though partially, to the regional economic dynamics, is part of a territory that, according to Abramovay (1999), represents a web of relation with historical roots, politic configurations and identities that play a role still little known in the economic development of the regions. According to Santos and Oliveira (2006), in the territory it may be considered the interdependence and the inseparability between the materiality, which includes nature and its use, in other words, the human action, the work. For the authors, it may also be considered the past and present actions, already frozen in the objects.

To integrate even more the region to the economic development of the State of Santa Catarina, measures that promoted the colonization of this are were taken, from the concession of lands to the colonizing businesses, which before the sells ex- 
plored the hardwoods of the region. The colonizers (real state of that period) received the lands from the government of Santa Catarina and should promote the occupation of the area and the opening of roads to the transport and displacement of settlers and, later, of the surplus production (BAVARESCO, 2005), to surrounding regions, and this proximity between production and consume environments was determined by the lack of regional ways, to the production flow.

In this discussion it is emerged the need for understanding the territory, once that it is not only set by its physical nature, but also, by the elements of human or social character. According to Haesbaert (2004), the territory is characterized as a space that cannot be considered strictly natural, nor only politic, economic or cultural: it may be conceived through an integrative perspective among the different dimensions, the one from the society and the one from the own nature. The concept of territory assumes the existence of power relations, either defined by legal, politic, social or economic relations, and not that traditional understanding linked only to the physical environment anymore, on the contrary, it is necessary to consider all the web of visible and invisible relations that are processed on it and that the connection networks among the different regions and also in the intra-regional scope (EGLER, 2003).

On this perspective, the territory must be seen as something that is in process, dynamic, a form-content, the hyphen between the past, the present and the immediate future. It must be seen as a strength filed, as an exercise place, of contradictions between the state and the market, between the economic use and the social use of the resources (ETGES; DEGRANDI, 2013).

Thereby, the regional territory is like a base to the processes of human settlements, because of its physical nature. The territory is characterized as a space that cannot be considered strictly natural, nor only politic, economic, structural or cultural: it has to be conceived by means of an integrative perspective among the different dimension, the one of the society and the one of the nature itself (HAESBAERT, 2004). In that time, the precariousness of the regional slip roads and the distance from the most dynamic commercial centers imposed some limits to the process of endogenous development, and the economic activities were limited to the availability of natural resources. However, from the extractive activities, as the logging, the first forms of commerce that had contact with the neighboring States arose, therefore, with the regional (KONRAD; DA SILVA, 2012).

Still on the twentieth century, new economic activities were organized and spread on the territory of AMOSC's region. A part of it was linked to agribusiness (polyculture) and represented a survival possibility, by the food subsistence that pro- 
vided the trade to social groups, through barter and the incipient surplus commercialization (BERNARDY; ZUANAZZI; MONTEIRO, 2008). Another factor of this period was the rise of the new space of industrial settlement, represented by the City of Chapecó, which started to show fast urbanization and industrialization progresses, a factor that attracted numerous regional population contingents; this phenomenon was vital to define the roles of the municipalities of the region between polarizer center and polarized environments.

This way, there was a restructuration of the region to the agroindustrial model, and the food industry became the main factor of the territory organization (BAVARESCO, 2005), there was a complementarity between the rural and urban activities. Propagated in dominant social groups in the territory that did not distinguish the "economic identity" of the producers, this model was vital to the enlargement of a concentrated and disperse urbanization process (BERNARDY; MONTEIRO; ZUANAZZI, 2008), which formed an incomplete network of cities.

The main economic support based on the rural familiar production linked to the food industry of Western Santa Catarina became, gradually, "selective", what caused the migration of numerous rural population contingents to new urban spaces, either local or regional and national (TESTA et al., 1996). According to Mior (2005), this production system presented a growing incompatibility among the specialization strategies and standardized scale to the familiar production, by the agroindustry, and the situation lived by the familiar farmers.

In this selectivity, the functional regions link and interconnect themselves and they are not seen on the beneath the character of the spatial uniformity, however, of the multiple relations that circulate and form a space that is internally differentiated (GOMES, 2003). Reis (2002, p. 10), when mentioned the dimensions of the territorial dynamics' structure (the proximity, the context and the density), concepts the "[...] structural polymorphism, which is the capacity that the territories have to produce differences therein, based on wider orders." (our translation). A part of this perspective rises with the valorization of the city's role as center of the spatial organization, in this case, of the industrial activities, in other words, the command of the region happens from the decision taken in the urban environment, which has more human capital and diversity of economic activities, including of public services.

From the cities of this study, in Chapecó, SC this condition is even more evident, because of the role that it plays on its respective region, composed by an incomplete urban network, with strong polarization, therefore, the City of Chapecó is constituted as the center of the region, by the centrality of the decisions and by the 
greater diversity of essential economic activities, which are structured in these urban environment, factors that reflect, in a decisive way, in the mobility of the population. According to Instituto Brasileiro de Geografia e Estatística (IBGE) [Brazilian Institute of Geography and Statistics] (2014, p. 15), “[...] in an hinterland, an urban center is dependent on the ones that are hierarchically superior to him, once the access to goods and services that are not locally available is necessary." (our translation). When addressing the participation in a network, "[...] the city gets independency of its immediate context, relating to economic processes in other scales, generating and performing productive, new and creative activities." (INSTITUTO BRASILEIRO DE GEOGRAFIA E ESTATÍSTICA, 2014, p. 15, our translation).

Thus, “[...] the cities (and in consequence, the municipalities) organize their hinterland, their area of influence or polarized region and also organize other small urban centers, in a true spatial system" (our translation), hierarchic and asymmetric, with well-defined functions, including to the rural environment. According Gomes (2003, p. 64, 70), "[...] the regions are the result of the division of the space and that is in principle essentially submitted always to the same variables, defining, for, through this division, a classificatory, uniform and hierarchic spatial system” (our translation), with well-defined functions.

On the understanding of this spatial selectivity, it is emerged the territory that, on Reis's (2002, p. 10) point of view, is characterized as “[...] holder of an own role and meaning, not only complementary and even less derivative of determinations in which a hierarchic relation, dependent or successive, is established.” (our translation). In the environment of this study it is evidenced a regional configuration strongly marked by the asymmetries among the municipalities, from the economic point of view, in other words, the standard one, in the typology and diversity of economic activities, in the population variation (retraction and concentration) and in the location of public equipment (service offer).

The presence of regional asymmetries is still determined by the incomplete urban network, internal and extra-regional significant population mobility, diversification of economic activities in city (municipality) pole (centrality of the region), economic homogenization in the rural environment, contributing to the formation of regional imbalances. Nowadays, certain configurations are presented to AMOSC's regional space: processes of devitalization of rural notorious spaces determined by regional mobility, which have caused an homogenization in the economic activities; stabilization and urban retraction of small municipalities and cities; population concentration in certain lar- 
ger urban centers; appearance of new economic dynamics as rural, by the concentration of earth, as urbans (BERNARDY; MONTEIRO; ZUANAZZI, 2008).

Certain municipalities from AMOSC’s region, like Chapecó, have presented a rise of other economic sector in the last decades: the service sector, both private and public. Although there is a spatial selectivity in their location, in larger cities it is also observed that it is developed in environments that had had a previous industrialization process, though some economic activities do not have straight relation, as in health and education areas. To the smaller municipalities, with strong specialization in agribusiness activities, the urban centers have a few economic vitalities, normally centered in the commerce and public services, generated by the activities of the city halls.

\section{METHODOLOGICAL PROCEDURES}

For the comprehension of AMOSC's socioeconomic and demographic dynamic, in this research it is performed an analysis of quantitative secondary data, from different institutions, and the research has an analytical descriptive character. Studies like this " $[\ldots]$ expose characteristics of certain phenomenon and they can also stablish correlation among variables and define its nature.” (VERGARA, 2011, p. 42, our translation). In relation to the approach, it is a quantitative study, and this analysis have as main advantage the record of information of the data collected and the immediate correlation between questions and answers, in order to accomplish the aims of the research (COLLINS; HUSSEY, 2005). The secondary data are linked to two big groups of variables.

a) Population evolution and variation from 1970 until 2010; demographic growth in AMOSC's municipalities, from 1970 to 2010 (\% per year) and annual demographic average growth by AMOSC's municipality, between 2000 and 2010 (\%).

b) Evolution of economic aggregates, as the total and per capita Gross Domestic Product (GDP), at current prices; Gross Added Values (GAV) at current prices, of the agribusiness, the industry and the services, and balance of jobs in December $31^{\text {st }}$, total and by sector.

The data are from Instituto Brasileiro de Geografia e Estatística (IBGE) [Brazilian Institute of Geography and Statistic], from Ministério do Trabalho e Emprego (MTE) [Ministry of Labor and Employment] and from Ministério do Desenvolvimen- 
to, Indústria e Comércio Exterior (MDIC) [Ministry of Development, Industry and Foreign Trade], so, from official organs and from different temporalities, in this case, to a more integral understanding of the phenomena of the research, once it allows to perform comparatives among the statistical series.

This way, as a research strategy, it was decided by the case study, in AMOSC's municipalities, in Santa Catarina. The specificity of this study is " $[\ldots]$ in the kind of question that it answers whose interest focus is in the specific" (our translation), in the private (GODOY, 2010, p. 119). It is considered that the case study is indicated when the researchers want to face practical problems like this of the socioeconomic and demographic dynamic (GODOY, 2010). Even without the ambition of extrapolating from this to other cases, this one was chosen for the researchers have already performed other studies about this institutional region, what provides more familiarity with the local of the research.

\section{BRIEF CHARACTERIZATION OF THE ENVIRONMENT OF THE RESEARCH}

In the state of Santa Catarina, in the 60s, the Associations of Municipalities were instituted; they were not static regionalization, once there were changes on the quantity of administrative units, being usual the migration of municipalities from an Association to the other, and from the half of the 90s, they stabilized in relation to the quantity of members.

In this sense, the Association of the Municipalities of Santa Catarina is one of the oldest - there are 21 Associations in the State, currently -, with initial formation covering 34 municipalities of Western Santa Catarina, AMOSC suffered, during its historical course, a process of territorial division, which was characterized by the formation of new municipalities and by the creation of two new Associations: the Associação dos municípios do Entre Rios (AMERIOS) [Association of the Municipatilies of Entre Rios] based in Maravilha, SC and the Associação dos Municípios do Nordeste Catarinense (AMNOROESTE) [Association of the Municipalities of the Northeast of Santa Catarina] based in São Lourenço do Oeste, SC in 1996 (ASSOCIAÇÃO DOS MUNICÍPIOS DO OESTE DE SANTA CATARINA, 2014).

Nowadays, AMOSC is composed by the municipalities of Águas de Chapecó, Águas Frias, Caxambu do Sul, Chapecó, Cordilheira Alta, Coronel Freitas, Formosa do Sul, Guatambu, Irati, Jardinópolis, Nova Erechim, Nova Itaberaba, Pinhalzinho, Planalto Alegre, Quilombo, São Carlos, Santiago do Sul, Serra Alta, Sul Brasil and 
União do Oeste. Together, these municipalities cover a territorial area of 2,955 km², according to Map 1 (ASSOCIAÇÃO DOS MUNICÍPIOS DO OESTE DE SANTA CATARINA, 2014).

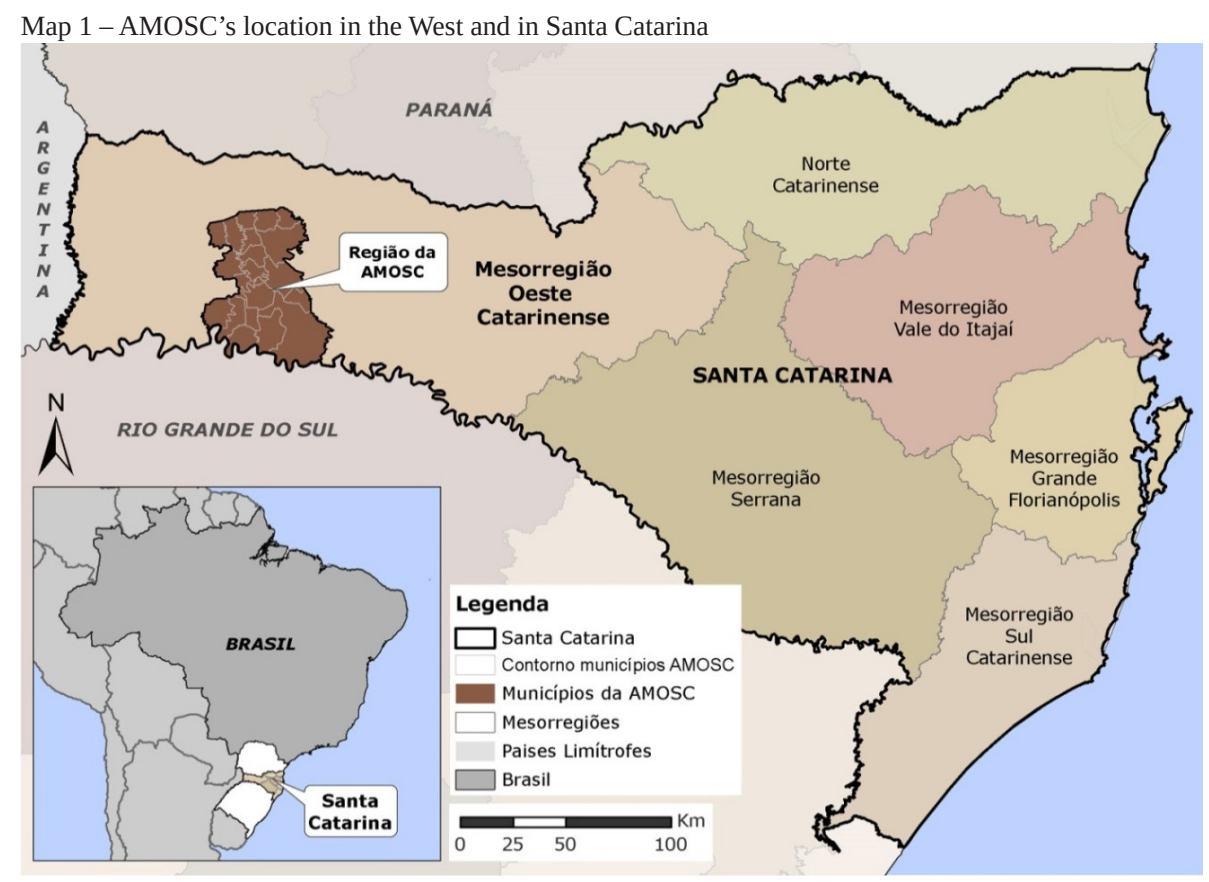

Source: Instituto Brasileiro de Geografia e Estatística (2013).

Note: Edition: Juliana Rammé.

AMOSC has 20 municipalities that cover a territorial area of 2,955 $\mathrm{km}^{2}$. It is observed that three periods were important in relation to the territorial division of the municipalities that compose AMOSC: before the 60s; in the 60s, both before the formation of the Association, an in the 90s (ASSOCIAÇÃO DOS MUNICÍPIOS DO OESTE DE SANTA CATARINA, 2014).

In the territorial division of AMOSC's municipalities, it is observed that, from the initial base represented by Chapecó's territory, blocks of new municipalities in temporalities and near geographic areas were formed, what allows the identification of the following typologies:

a) in the 50s and 60s of the twentieth century, municipalities with distance superior to $20 \mathrm{~km}$ from the City of Chapecó were formed; 
b) in the 80s and 90s, new municipalities, specially located North of AMOSC, thus, geographically distant from the City of Chapecó were formed;

c) the last emancipations happened specially in 1991 and 1992 and they were structured near the municipal center of Chapecó and were represented by districts that were located at distances shorter than $20 \mathrm{~km}$ (BERNARDY; MONTEIRO; ZUANAZZI, 2008).

\section{THE DEMOGRAPHIC DYNAMICS AND THE ECONOMIC ACTIVITIES}

The data analysis is of this research is focused in two sequences: demographical evolution and variation in AMOSC, from 1970 till 2010, and evolution of the economic aggregates, based on quantitative approach and interpretative analysis, in sections 5.1 and 5.2 .

\subsection{DEMOGRAPHIC EVOLUTION AND VARIATION IN AMOSC}

AMOSC's total population presents a growth picture between the demographic census of 2000 and 2010, above the growth showed in the Mesoregion West of Santa Catarina. The average rate of demographic growth of AMOSC's municipalities was $1.56 \%$ per year (Table 1), while this rate in the mesoregion in which AMOSC is inserted was $0.73 \%$. Interesting to add that in Santa Catarina state and in Brazil, this rate was $1.55 \%$ and $1.17 \%$, respectively (INSTITUTO BRASILEIRO DE GEOGRAFIA E ESTATÍSTICA, 2010). Despite registering a demographic growth above the average growth of the Mesoregion West of Santa Catarina and similar to the State growth, among AMOSC's municipalities, this performance was unequal. 
Rógis Juarez Bernardy et al.

Table 1 - Evolution of the population by AMOSC’s Municipality - 1970 to 2010

\begin{tabular}{|c|c|c|c|c|c|c|c|}
\hline \multirow{2}{*}{ Municipality } & \multirow{2}{*}{1970} & \multirow{2}{*}{1980} & \multirow{2}{*}{1991} & \multirow{2}{*}{2000} & \multirow{2}{*}{2010} & \multicolumn{2}{|c|}{ Var. 00-10(\%) } \\
\hline & & & & & & Total & Average \\
\hline Águas de Chapecó & 6.803 & 6.603 & 6.443 & 5.782 & 6.110 & 5,67 & 0,55 \\
\hline Águas Frias & 0 & 0 & 0 & 2.525 & 2.424 & $-4,00$ & $-0,41$ \\
\hline Caxambu do Sul & 8.584 & 9.009 & 8.532 & 5.263 & 4.411 & $-16,19$ & $-1,75$ \\
\hline Chapecó & 49.865 & 83.772 & 123.050 & 146.967 & 183.530 & 24,88 & 2,25 \\
\hline Cordilheira Alta & 0 & 0 & 0 & 3.093 & 3.767 & 21,79 & 1,99 \\
\hline Coronel Freitas & 16.185 & 19.168 & 11.886 & 10.535 & 10.213 & $-3,06$ & $-0,31$ \\
\hline Formosa do Sul & 0 & 0 & 0 & 2.725 & 2.601 & $-4,55$ & $-0,46$ \\
\hline Guatambu & 0 & 0 & 0 & 4.702 & 4.679 & $-0,49$ & $-0,05$ \\
\hline Irati & 0 & 0 & 0 & 2.202 & 2.096 & $-4,81$ & $-0,49$ \\
\hline Jardinópolis & 0 & 0 & 0 & 1.994 & 1.766 & $-11,43$ & $-1,21$ \\
\hline Nova Erechim & 2.557 & 3.252 & 3.114 & 3.543 & 4.275 & 20,66 & 1,90 \\
\hline Nova Itaberaba & 0 & 0 & 0 & 4.256 & 4.267 & 0,26 & 0,03 \\
\hline Pinhalzinho & 8.044 & 9.954 & 10.673 & 12.356 & 16.332 & 32,18 & 2,83 \\
\hline Planalto Alegre & 0 & 0 & 0 & 2.452 & 2.654 & 8,24 & 0,79 \\
\hline Quilombo & 15.914 & 21.453 & 19.362 & 10.736 & 10.248 & $-4,55$ & $-0,46$ \\
\hline Santiago do Sul & 0 & 0 & 0 & 1.696 & 1.465 & $-13,62$ & $-1,45$ \\
\hline São Carlos & 10.358 & 11.625 & 12.230 & 9.364 & 10.291 & 9,90 & 0,95 \\
\hline Serra Alta & 0 & 0 & 3.861 & 3.330 & 3.285 & $-1,35$ & $-0,14$ \\
\hline Sul Brasil & 0 & 0 & 0 & 3.116 & 2.766 & $-11,23$ & $-1,18$ \\
\hline União do Oeste & 0 & 0 & 7.234 & 3.391 & 2.910 & $-14,18$ & $-1,52$ \\
\hline TOTAL & 118.310 & 164.836 & 206.385 & 240.028 & 280.090 & 16,69 & 1,56 \\
\hline
\end{tabular}

Source: Instituto Brasileiro de Geografia e Estatística (2014b).

Note: The municipalities with no population in 1970, 1980 and 1991 were dismembered of other municipalities, after these dates.

The growth rates, however, have been declining when it is considered the initial period of the historical series, since 1970 (Table 1). Although the growth is characterized in moderate levels in the two last demographical census, it should be noted its slowdown. The average growth was 3.37\% per year between 1970 and 1980, 2.05\% per year between 1980 and 1991, 1.69 per year between 1991 and 2000, and 1.56 per year between 2000 and 2010 (Graphic 1). 


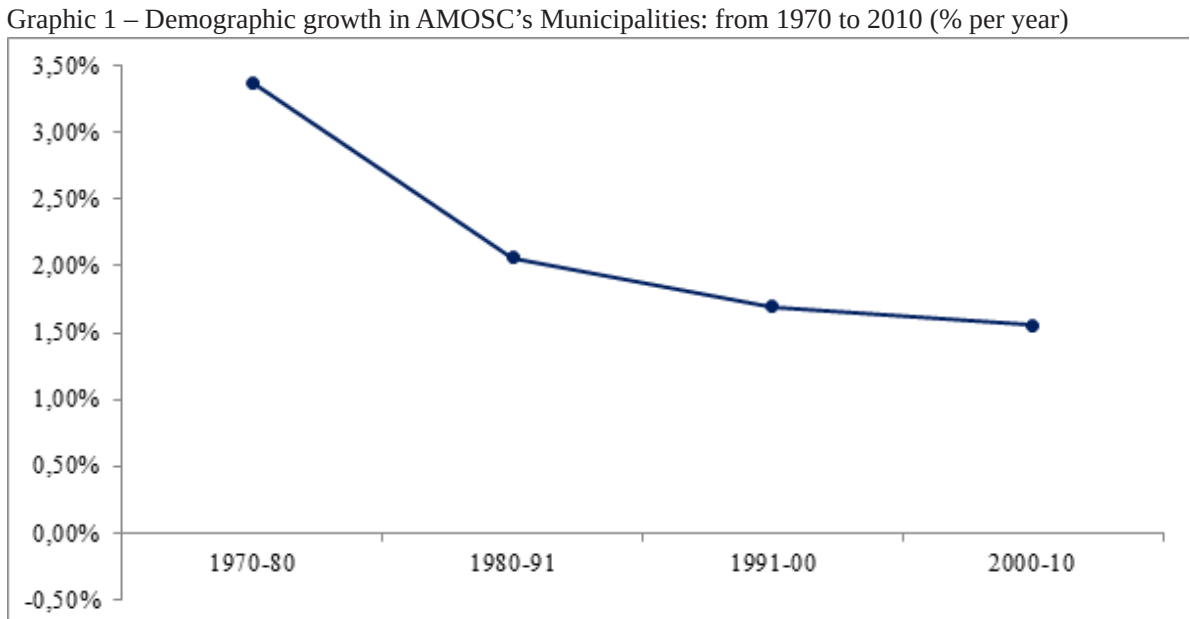

Source: Instituto Brasileiro de Geografia e Estatística (2014b).

The decrease of the demographic growth rates in the municipalities considered in this research has been happening during the observed periods of this study and were the sharpest ones between 1970 and 1991. However, this is not an isolated phenomenon for the analyzed context, since the birth rates have been reduced in all Brazilian territory. According to IBGE's statistical series, the average geometrical rate of annual growth of the population is declining since 1960, whose main cause is the decrease of the fertility rate (in 1960, 3\%, and in 2010, slightly more than 1\%).

Besides the slowdown tendency, the demographic growth among AMOSC's municipalities is very unequal (Table 1). From the twenty analyzed municipalities, only seven grew, of which it can be highlighted Pinhalzinho and Chapecó. Both municipalities registered an average growth rate of $2.29 \%$ per year, whose population that represented 66.4\%, in 2000, of AMOSC's population, in 2010 represented 71.4\%. On one hand, coincidently, these two municipalities account for $75.8 \%$ of the Gross Domestic Product (GDP) of the studied area, inferring that the greater dynamism of the economic activities, besides fixing the local population, attracts people from other cities of the same region also of other ones. By the other hand, the other municipalities registered total demographic reduction of 5.9\% in the period of 2000 to 2010 (Graphic 2). 


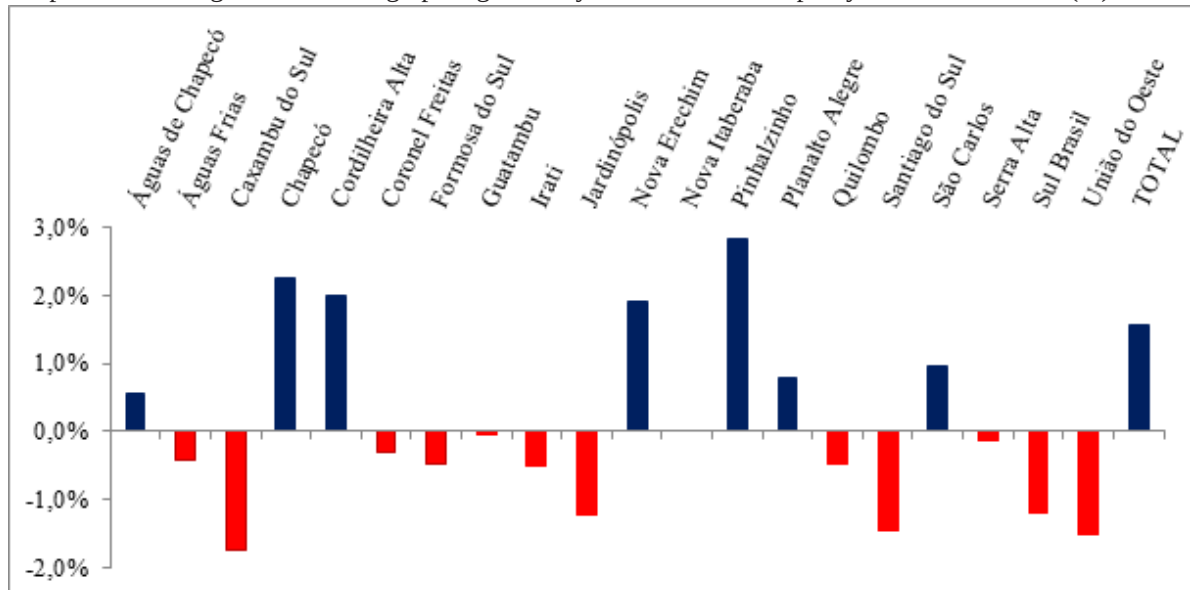

Source: Instituto Brasileiro de Geografia e Estatística (2014b).

The ascending or descending directions of the demographic growth are generally associated to the social and economic conditions of the geographic spaces. In the case of the Municipality of Pinhalzinho, it presents the highest relative growth, due to the diversification of the industrial activities in area of direct influence of an international highway corridor (highway BR-282). Chapecó, which presents the second highest growth among the analyzed municipalities, accounts for more than $65 \%$ of the GDP at the region's current prices, and it is constituted as a regional pole, with economic basis centered in agroindustry and in the service provision section.

In this case, these two municipalities' economic growth is partially determined by the location, since the demographic growth is firmly linked to the municipalities' location near the main extra-regional connection highway. It is also highlighted that the municipalities with higher population descending variations have certain isolation condition, by the incipient urban network and distance from the main regional center (City of Chapecó). Thus, the study points to an unequal demographic growth among the municipalities and its slowdown. The municipalities most populous, which, by coincidence, have more dynamic economies, present higher growth rates, while most of the municipalities with less than ten thousand inhabitants present negative growth rates.

\subsection{ECONOMIC AGGREGATES’ EVOLUTION}

The analysis of the economic dynamic of AMOSC's municipalities was centered in total and per capita Gross Domestic Product (GDP), on Gross Added Val- 
ues (VAB) of the Agriculture and cattle raising, Industry, Services and Total. These aggregates' data, extracted from IBGE's basis, are referred to the period from 2000 to 2010. Data at current prices were considered, which were deflated in order to obtaining the real growths, having as base the rates of Índice de Preços ao Consumidor Amplo (IPCA) [National Extended Consumer Price Index] ascertained monthly by IBGE, which is the official inflation index used by the government. The total GDP by municipality and its relative participation in AMOSC's GDP and the GDP per capita by municipality are presented on Table 2 .

Table 2 - Total and per capita GDP in AMOSC's municipalities in 2000 and 2010

\begin{tabular}{|c|c|c|c|c|c|c|c|c|}
\hline \multirow{2}{*}{ Municipality } & \multicolumn{3}{|c|}{ Total GDP (R\$ Thousand) } & \multicolumn{2}{|c|}{$\begin{array}{l}\text { AMOSC's } \\
\text { participation in } \\
\text { GDP }(\%)\end{array}$} & \multicolumn{3}{|c|}{ Per capita GDP (R\$) } \\
\hline & 2000 & 2010 & $\begin{array}{l}\text { Annual } \\
\text { growth } \\
(\%) \\
\end{array}$ & 2000 & 2010 & 2000 & 2010 & $\begin{array}{l}\text { Annual } \\
\text { growth } \\
(\%)\end{array}$ \\
\hline Águas de Chapecó & 22.791 & 62.209 & 10,56 & 1,15 & 2,19 & 3.942 & 10.181 & 9,95 \\
\hline Águas Frias & 10.641 & 26.987 & 9,75 & 0,54 & 0,95 & 4.214 & 11.133 & 10,20 \\
\hline Caxambu do Sul & 26.862 & 29.531 & 0,95 & 1,36 & 1,04 & 5.104 & 6.695 & 2,75 \\
\hline Chapecó & 1.485 .167 & 1.954 .648 & 2,78 & 75,06 & 68,85 & 10.105 & 10.650 & 0,53 \\
\hline Cordilheira Alta & 34.117 & 58.780 & 5,59 & 1,72 & 2,07 & 11.030 & 15.604 & 3,53 \\
\hline Coronel Freitas & 49.062 & 87.489 & 5,95 & 2,48 & 3,08 & 4.657 & 8.566 & 6,28 \\
\hline Formosa do Sul & 10.198 & 18.781 & 6,30 & 0,52 & 0,66 & 3.742 & 7.221 & 6,79 \\
\hline Guatambu & 18.788 & 60.075 & 12,33 & 0,95 & 2,12 & 3.996 & 12.839 & 12,38 \\
\hline Irati & 10.009 & 13.479 & 3,02 & 0,51 & 0,47 & 4.546 & 6.431 & 3,53 \\
\hline Jardinópolis & 8.325 & 9.466 & 1,29 & 0,42 & 0,33 & 4.175 & 5.360 & 2,53 \\
\hline Nova Erechim & 18.869 & 34.156 & 6,11 & 0,95 & 1,20 & 5.326 & 7.990 & 4,14 \\
\hline Nova Itaberaba & 18.004 & 29.690 & 5,13 & 0,91 & 1,05 & 4.230 & 6.958 & 5,10 \\
\hline Pinhalzinho & 88.330 & 198.299 & 8,42 & 4,46 & 6,98 & 7.149 & 12.142 & 5,44 \\
\hline Planalto Alegre & 11.407 & 15.537 & 3,14 & 0,58 & 0,55 & 4.652 & 5.854 & 2,33 \\
\hline Quilombo & 72.780 & 92.455 & 2,42 & 3,68 & 3,26 & 6.779 & 9.022 & 2,90 \\
\hline Santiago do Sul & 9.056 & 10.615 & 1,60 & 0,46 & 0,37 & 5.340 & 7.246 & 3,10 \\
\hline São Carlos & 46.691 & 79.810 & 5,51 & 2,36 & 2,81 & 4.986 & 7.755 & 4,52 \\
\hline Serra Alta & 13.383 & 23.327 & 5,71 & 0,68 & 0,82 & 4.019 & 7.101 & 5,86 \\
\hline Sul Brasil & 11.215 & 15.779 & 3,47 & 0,57 & 0,56 & 3.599 & 5.705 & 4,71 \\
\hline União do Oeste & 12.928 & 18.021 & 3,38 & 0,65 & 0,63 & 3.812 & 6.193 & 4,97 \\
\hline TOTAL & 1.978 .624 & 2.839.133 & 3,68 & 100,00 & 100,00 & 8.243 & 10.137 & 2,09 \\
\hline
\end{tabular}

Source: Instituto Brasileiro de Geografia e Estatística (2014c). 
In comparison with the Mesoregion West of Santa Catarina, AMOSC had a medium GDP growth, more than half a percentage point superior. In the period, the GDP of the Mesoregion grew 36.0\%, while AMOSC's GDP grew 46.5\%. However, compared to Santa Catarinas's and Brazil's GDP's performance, AMOSC's GDP growth was smaller, in 2.1 and 1.1 percentage points, respectively. In the period, the state’s GDP grew $75.0 \%$, and the national GDP growth was of 58.9\%.

In the period of 2000 to 2010, there was a short decentralization of the total GDP, since the municipalities of Chapecó, Pinhalzinho, Quilombo, Coronel Freitas and São Carlos had the participation of $88.0 \%$ of the GDP in 2000, and had the participation of $85.0 \%$ in 2010. Chapecó had the highest loss of participation (6.2\%), in the opposite of Pinhalzinho, Guatambu and Águas de Chapecó’s progress, which increased their participation in 2.5\%, $1.2 \%$ and $1.0 \%$, respectively.

Cordilheira Alta kept the highest AMOSC's GDP per capita, and in this index, Chapecó has gone from second to fifth position, giving way to Guatambu, Pinhalzinho and Águas Frias. This situation results from the fact that the GDP's growth has accelerated more than the demographic growth in smaller municipalities, or from the inverse evolution, in which the GDP grew in face of the population decrease, which is the case of Águas Frias. Anyway, this behavior points to a small decentralization of GDP in the region, an interesting fact if it is considered the significant asymmetry of the region nowadays.

Comparatively to the Mesoregion West of Santa Catarina, AMOSC's per capita GDP, which in 2000 was 5.9\% superior, reduced the difference to $2.9 \%$ in 2010 . In comparison to the State of Santa Catarina, its difference fell from $1.9 \%$ superior to 16.4\% smaller. Before the per capita DGP, the difference fell from 18.7\% to 3.2\%. The reduction of the differences in comparison to the contexts before which AMOSC was heading characterize the loss of dynamism of AMOSC's economic activities, as well as of the Mesoregion West of Santa Catarina. AMOSC's GDP performance was characterizes by sharp oscillations during the analyzed period with the trend of growth decrease, setting bias of economic depression (Graphic 3). 
Graphic 3 - Annual variation of AMOC’s GDP from 2000 and 2010 (\%)

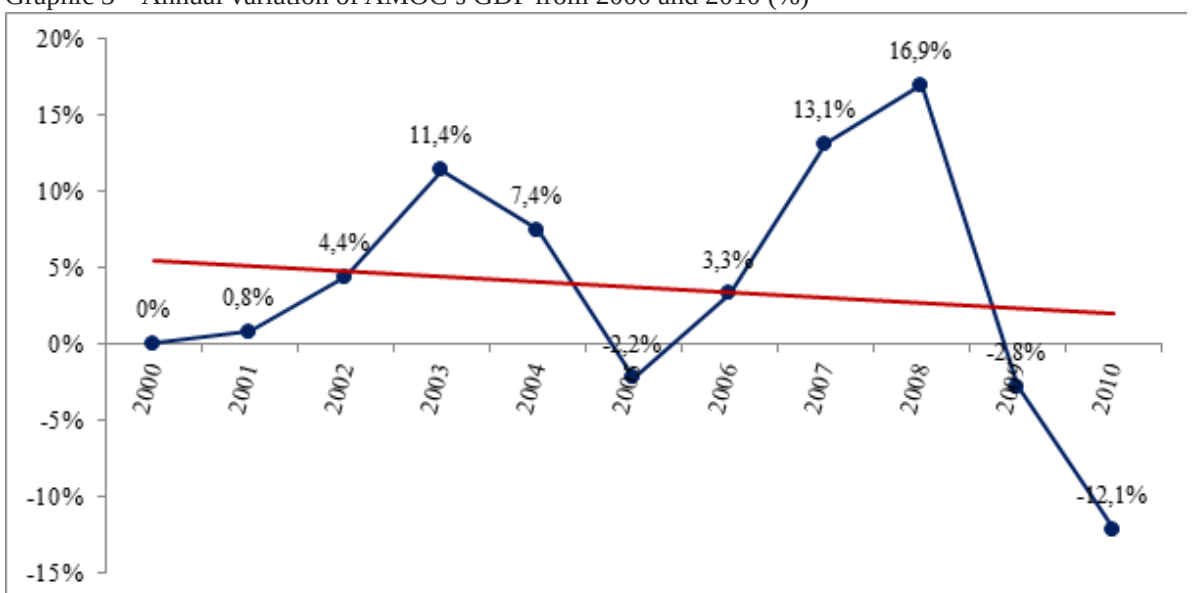

Source: based on Instituto Brasileiro de Geografia e Estatística (20014c).

GDP decreased in 2005, influenced by weather phenomena such as drought, which harmed the agriculture and cattle raising, and the foreign embargo to pork, which also harmed the industrial activity, resulting in a decrease of $12.8 \%$ and $3.4 \%$ of the agribusiness and the industry, respectively. The highest annual growths happened in 2007 and 2008, which were interrupted by the international financial crisis from the late 2008, resulting in sharp falls in the following years.

The Mesoregion West of Santa Catarina, where AMOSC is inserted, has its economic activities based on agribusiness, with significant participation in export issues, mainly in the sectors of poultry and pork. These activities suffered with the export decrease in consequence of the global financial crisis that also impacted strongly other sectors, though there is a recovery prospect of this scenario, in the global scope.

However, financial crisis is not the only cause of GDP decrease in the region. The economy of the region also suffers with the precariousness of the logistics infrastructure, pointed out as one of the main causes of displacement of industrial facilities to other regions, culminating a reduction tendency of the dynamism of regional economic activities.

This behavior infers that the region registered a small economic growth, pointing out to the low dynamism of the general economic activity, what is confirmed by the development of the indicators of the sectorial Gross Added Values (GAVs). The Tables 3 and 4 show the real total values - base year 2000 - the average variations and the sectorial GAVs relative participations in the Total GAV. The participation in economic activities by the agribusiness and industry sectors went from $9.9 \%$ and $39.4 \%$, 
in 2000, to 7.6 and $30.7 \%$, in 2010, respectively. The participation of the service sector went from 50.7\%, in 2000, to 61,6\%, in 2010 (Table 3).

Table 3 - Agricultural Gross Added Value (Agri GAV) and Industrial (Industrial GAV): R\$ thousand = base 2000

\begin{tabular}{|c|c|c|c|c|c|c|c|c|c|c|}
\hline \multirow{3}{*}{ Municipality } & \multicolumn{5}{|c|}{ Agricultural GAV } & \multicolumn{5}{|c|}{ Industrial GAV } \\
\hline & \multirow[t]{2}{*}{2000} & \multirow[t]{2}{*}{2010} & \multirow{2}{*}{$\begin{array}{l}\text { Average } \\
\text { change } \\
(\%)\end{array}$} & \multicolumn{2}{|c|}{$\begin{array}{l}\text { Particip. on } \\
\text { Total GAV } \\
(\%) \\
\end{array}$} & \multirow[t]{2}{*}{2000} & \multirow[t]{2}{*}{2010} & \multirow{2}{*}{$\begin{array}{l}\text { Average } \\
\text { change } \\
(\%)\end{array}$} & \multicolumn{2}{|c|}{$\begin{array}{l}\text { Particip. on } \\
\text { Total GAV } \\
(\%) \\
\end{array}$} \\
\hline & & & & 2000 & 2010 & & & & 2000 & 2010 \\
\hline $\begin{array}{l}\text { Águas Cha- } \\
\text { pecó }\end{array}$ & 11.272 & 10.774 & $-0,45$ & 50,7 & 17,8 & 1.487 & 30.704 & 35,36 & 6,7 & 50,6 \\
\hline Águas Frias & 4.777 & 6.057 & 2,40 & 46,8 & 21,5 & 687 & 5.454 & 23,01 & 6,7 & 19,4 \\
\hline $\begin{array}{l}\text { Caxambu do } \\
\text { Sul }\end{array}$ & 14.011 & 10.016 & $-3,30$ & 53,5 & 35,1 & 1.807 & 3.968 & 8,18 & 6,9 & 13,9 \\
\hline Chapecó & 28.658 & 26.380 & $-0,83$ & 2,2 & 1,4 & 620.029 & 588.140 & $-0,53$ & 46,6 & 32,0 \\
\hline $\begin{array}{l}\text { Cordilheira } \\
\text { Alta }\end{array}$ & 4.706 & 2.579 & $-5,84$ & 16,9 & 4,4 & 2.074 & 15.227 & 22,06 & 7,4 & 25,8 \\
\hline $\begin{array}{l}\text { Coronel } \\
\text { Freitas }\end{array}$ & 14.125 & 27.209 & 6,78 & 30,4 & 34,0 & 10.037 & 16.636 & 5,18 & 21,6 & 20,8 \\
\hline $\begin{array}{l}\text { Formosa do } \\
\text { Sul }\end{array}$ & 4.228 & 7.160 & 5,41 & 42,7 & 41,3 & 775 & 1.845 & 9,06 & 7,8 & 10,6 \\
\hline Guatambu & 7.307 & 7.412 & 0,14 & 40,9 & 12,0 & 3.460 & 37.775 & 27,00 & 19,4 & 61,3 \\
\hline Irati & 4.857 & 5.521 & 1,29 & 49,6 & 43,2 & 610 & 1.350 & 8,26 & 6,2 & 10,6 \\
\hline Jardinópolis & 3.899 & 2.420 & $-4,66$ & 47,8 & 27,4 & 518 & 1.020 & 7,00 & 6,4 & 11,5 \\
\hline $\begin{array}{l}\text { Nova Ere- } \\
\text { chim }\end{array}$ & 5.168 & 5.621 & 0,84 & 28,9 & 16,3 & 3.664 & 11.757 & 12,37 & 20,5 & 34,1 \\
\hline $\begin{array}{l}\text { Nova Itabe- } \\
\text { raba }\end{array}$ & 8.262 & 8.033 & $-0,28$ & 47,6 & 30,0 & 2.227 & 7.713 & 13,22 & 12,8 & 28,8 \\
\hline Pinhalzinho & 12.589 & 10.011 & $-2,27$ & 15,8 & 6,1 & 21.251 & 54.177 & 9,81 & 26,7 & 32,9 \\
\hline $\begin{array}{l}\text { Planalto } \\
\text { Alegre }\end{array}$ & 4.797 & 4.540 & $-0,55$ & 43,4 & 28,1 & 1.240 & 3.120 & 9,67 & 11,2 & 19,3 \\
\hline Quilombo & 15.178 & 24.842 & 5,05 & 22,1 & 31,1 & 26.490 & 12.489 & $-7,24$ & 38,6 & 15,6 \\
\hline $\begin{array}{l}\text { Santiago do } \\
\text { Sul }\end{array}$ & 4.769 & 4.399 & $-0,80$ & 53,6 & 43,4 & 418 & 812 & 6,86 & 4,7 & 8,0 \\
\hline São Carlos & 13.002 & 17.631 & 3,09 & 30,4 & 24,2 & 6.266 & 16.924 & 10,45 & 14,7 & 23,2 \\
\hline Serra Alta & 4.811 & 7.131 & 4,01 & 37,7 & 33,3 & 1.685 & 3.760 & 8,36 & 13,2 & 17,5 \\
\hline Sul Brasil & 5.718 & 7.435 & 2,66 & 52,1 & 45,3 & 630 & 1.788 & 11,00 & 5,7 & 10,9 \\
\hline $\begin{array}{l}\text { União do } \\
\text { Oeste }\end{array}$ & 5.518 & 6.920 & 2,29 & 43,8 & 40,6 & 1.013 & 1.697 & 5,29 & 8,0 & 10,0 \\
\hline TOTAL & 177.653 & 202.091 & 1,30 & 9,9 & 7,6 & 706.371 & 816.356 & 1,46 & 39,4 & 30,7 \\
\hline
\end{tabular}

Source: Instituto Brasileiro de Geografia e Estatística (2014c). 
Except Coronel Freitas and Quilombo, which increased the agriculture and cattle raising participation in their Total GAVs, the other AMOSC's municipalities reduced their participation in this sector. Chapecó and Quilombo reduced considerably the industry participation, while the other municipalities increased it (Table 4).

Table 4 - Service Gross Added Value (Services GAV) and Total (Total GAV): R\$ thousand = base 2000

\begin{tabular}{|c|c|c|c|c|c|c|c|c|}
\hline \multirow{3}{*}{ Municipality } & \multicolumn{5}{|c|}{ Services GAV } & \multicolumn{3}{|l|}{ Total GAV } \\
\hline & \multirow[t]{2}{*}{2000} & \multirow[t]{2}{*}{2010} & \multirow{2}{*}{$\begin{array}{l}\text { Annual } \\
\text { varia- } \\
\text { tion } \\
(\%)\end{array}$} & \multicolumn{2}{|c|}{$\begin{array}{l}\text { Particip. on } \\
\text { Total GAV } \\
\text { (\%) } \\
\end{array}$} & \multirow[t]{2}{*}{2000} & \multirow[t]{2}{*}{2010} & \multirow{2}{*}{$\begin{array}{l}\text { An- } \\
\text { nual } \\
\text { varia- } \\
\text { tion } \\
(\%)\end{array}$} \\
\hline & & & & 2000 & 2010 & & & \\
\hline Águas de Chapecó & 9.481 & 19.207 & 7,32 & 42,6 & 31,6 & 22.240 & 60.686 & 10,56 \\
\hline Águas Frias & 4.752 & 16.652 & 13,36 & 46,5 & 59,1 & 10.217 & 28.163 & 10,67 \\
\hline Caxambu do Sul & 10.389 & 14.580 & 3,45 & 39,6 & 51,0 & 26.207 & 28.564 & 0,86 \\
\hline Chapecó & 681.701 & 1.223 .960 & 6,03 & 51,2 & 66,6 & 1.330 .389 & 1.838 .480 & 3,29 \\
\hline Cordilheira Alta & 21.099 & 41.236 & 6,93 & 75,7 & 69,8 & 27.879 & 59.041 & 7,79 \\
\hline Coronel Freitas & 22.265 & 36.259 & 5,00 & 48,0 & 45,3 & 46.426 & 80.104 & 5,61 \\
\hline Formosa do Sul & 4.900 & 8.334 & 5,45 & 49,5 & 48,1 & 9.904 & 17.339 & 5,76 \\
\hline Guatambu & 7.109 & 16.419 & 8,73 & 39,8 & 26,7 & 17.876 & 61.606 & 13,17 \\
\hline Irati & 4.327 & 5.912 & 3,17 & 44,2 & 46,2 & 9.794 & 12.783 & 2,70 \\
\hline Jardinópolis & 3.744 & 5.393 & 3,72 & 45,9 & 61,1 & 8.161 & 8.833 & 0,79 \\
\hline Nova Erechim & 9.023 & 17.071 & 6,58 & 50,5 & 49,6 & 17.856 & 34.448 & 6,79 \\
\hline Nova Itaberaba & 6.858 & 11.029 & 4,87 & 39,5 & 41,2 & 17.347 & 26.774 & 4,44 \\
\hline Pinhalzinho & 45.751 & 100.627 & 8,20 & 57,5 & 61,1 & 79.590 & 164.815 & 7,55 \\
\hline Planalto Alegre & 5.017 & 8.502 & 5,41 & 45,4 & 52,6 & 11.054 & 16.162 & 3,87 \\
\hline Quilombo & 27.020 & 42.474 & 4,63 & 39,3 & 53,2 & 68.689 & 79.804 & 1,51 \\
\hline Santiago do Sul & 3.711 & 4.919 & 2,86 & 41,7 & 48,6 & 8.899 & 10.131 & 1,31 \\
\hline São Carlos & 23.442 & 38.437 & 5,07 & 54,9 & 52,7 & 42.711 & 72.992 & 5,51 \\
\hline Serra Alta & 6.279 & 10.550 & 5,33 & 49,2 & 49,2 & 12.775 & 21.442 & 5,32 \\
\hline Sul Brasil & 4.637 & 7.200 & 4,50 & 42,2 & 43,8 & 10.986 & 16.423 & 4,10 \\
\hline União do Oeste & 6.060 & 8.406 & 3,33 & 48,1 & 49,4 & 12.591 & 17.023 & 3,06 \\
\hline TOTAL & 907.566 & 1.637 .164 & 6,08 & 50,7 & 61,6 & 1.791 .589 & 2.655 .613 & 4,01 \\
\hline
\end{tabular}

Source: Instituto Brasileiro de Geografia e Estatística (2014c). 
The sector participation changes to the formation of added values are seen clearer in the municipalities individually. In 2000, the municipalities of Águas de Chapecó, Águas Frias, Guatambu, Irati, Jardinópolis, Nova Itaberaba, Santiago do Sul and Sul Brasil qualified in agriculture and cattle raising the largest share of their generations of added values. The other municipalities already concentrated the added value generation in the service sector. In 2010, the industry started to account for the largest share of the added values of the municipalities of Águas de Chapecó and Guatambu, and the service sector started to account for the aggregate in the other municipalities.

The added value growth reflects the loss of dynamism of the agricultural economic and industrial activities, because the added value growth of both was inferior to the GDP growth. The profile chance of the sectional participation of the economic activities results of several phenomena, like the technological changes and the evolution of the relative prices of input, which often conduct to a transference of production activities to the region where the costs are lower and where there is greater proximity with the consumer market.

In Western Santa Catarina there are conditions that have influenced the costs of inputs and the costs resulting from the logistic conditions of raw material supplies and of disposal of products. To the formation of flocks of poultry and pork, the West of Santa Catarina is not self-sufficient in the production of the main inputs, as corn and soy, and the natural conditions of the region, as climate and topography, do not enable the enlargement of cultivation of these grains. In order to meet the demand, the region depends on the complementation of the supply of these grains from other producer regions, including from new agricultural borders (Brazilian Mid-West), and this dependence increases the cost of inputs.

The infrastructure, mainly the precarious conditions of the roads, main via of input receiving and flow of production, constitutes another restriction to the expansion of the cooling processing industrial activities. The costs of inputs and the logistics ones are the main factors that compromise the competitiveness of the agribusiness of the region, limiting the expansion of the activities of the industrial and agricultural sectors, because they discourage the investments in enlargement of facilities of the agribusiness chain of the cooling segments.

Particularly, since the beginning of the 2000s, the displacement of the agroindustrial production of poultry and swine to the country's Mid-West and Southwest has happened, due to the search for lower costs mainly to inputs, and also better conditions of the road structure. This fact has become one of the worries expressed by the leaderships of the main economic sectors and by public leaderships of the region. As 
the economic base is strongly based on the agroindustry, the loss of competitiveness of this segment points to the tendency of regional economic depression and to the need to discuss alternatives that gradually reverse the main structural debts that attack the current production chain in the region.

\section{CONCLUSION}

The study allowed an analysis of the particularities of the socioeconomic dynamics AMOSC's municipalities, based on the evolution indicators and population variation in the last decades (official data from the demographical census from 1970 to 2010), as well as the evolution of the main economic aggregates, per municipality.

It was observed, about the demographic variation, that there is a perspective of increase of the regional asymmetries, once the population tends to concentrate in the center city of Chapecó, SC, rather than the formation of broad spaces with population retraction, in small cities. These factor are directly linked to the generation of job and income opportunities, and also specialized services, in regional level, therefore, the economic scenarios influence sharply in settlements.

In relation to the economic aggregates, it is observed a clear bias of stagnation and depression in the economic activities. This condition is related more strongly to the precariousness of the road infrastructure, encumbering appreciably the import of inputs to the pork and poultry chains, which comprise the prevailing activities of the economy of the region. The economic indicators confirm the loss of dynamism of the economic activities, already pointed by the leaderships of the region, when they debate the reversion alternatives of the tendencies of competitiveness decrease.

In a general manner, based on the analyzed variables, it is observed a deepening of the regional imbalances both internal and in relation to the state territory. The search for development alternatives becomes necessary to reverse the loss of the development levels, especially in comparison to other regional centers in the state of Santa Catarina and in the country.

\section{REFERENCES}

ABRAMOVAY, R. O capital social dos territórios: repensando o desenvolvimento rural. In: ENCONTRO DA SOCIEDADE BRASILEIRA DE ECONOMIA POLÍTICA, 4., 1999, Porto Alegre. Proceedings... Porto Alegre, 1999. 
ASSOCIAÇÃO DOS MUNICÍPIOS DO OESTE DE SANTA CATARINA. Municípios da Associação. Avalaible in: <www.amosc.org.br/municípios>. Access in: Apr. 202014.

BAVARESCO, R. Ciclos econômicos regionais: modernização e empobrecimento no Extremo Oeste Catarinense. Chapecó: Argos, 2005.

BERNARDY, R. J.; MONTEIRO, R. R.; ZUANAZZI, J. Território, planejamento e gestão: um estudo do Oeste catarinense a partir da região da AMOSC. Chapecó: Palotti, 2008.

COLLIS, J.; HUSSEY, R. Pesquisa em administração: um guia prático para alunos de graduação e pós-graduação. 2. ed. Porto Alegre: Bookman, 2005.

EGLER, C. A. G. Questão regional e gestão do território no Brasil. In: CASTRO, I. E. de; GOMES, P. C. da C.; CORRÊA, R. L. (Org.). Geografia, conceitos e temas. 6. ed. Rio de Janeiro: Bertrand Brasil, 2003.

ETGES, V. E.; DEGRANDI, J. O. Desenvolvimento Regional: a diversidade como potencialidade. Revista Brasileira de Desenvolvimento Regional, Blumenau, v. 1, i. 1, 2013.

GODOY, A. S. Estudo de caso qualitativo. In: GODOI, C. K.; MELLO, R. B. de; SILVA, A. B. da (Org.). Pesquisa qualitativa em estudos organizacionais: paradigmas, estratégias e métodos. 2. ed. São Paulo: Saraiva, 2010.

GOMES, P. C. da C. O conceito de região e sua discussão. In: CASTRO, I. E. de; GOMES, P. C. da C.; CORRÊA, R. L. (Org.). Geografia, conceitos e temas. 6. ed. Rio de Janeiro: Bertrand Brasil, 2003.

HAESBAERT, R. O mito da desterritorialização: do "fim dos territórios" à multiterritorialidade. Rio de Janeiro: Bertrand Brasil, 2004.

INSTITUTO BRASILEIRO DE GEOGRAFIA E ESTATÍSTICA. Censo demográfico de 2000. Brasília, DF. Avalaible in: <http://www.ibge.gov.br/home/estatistica/ populacao>. Access in: Set. 10 2014a.

INSTITUTO BRASILEIRO DE GEOGRAFIA E ESTATÍSTICA. Censo demográfico de 2010. Brasília, DF. Avalaible in: <http://www.ibge.gov.br/home/estatistica/ populacao>. Access in: Set. 10 2014b. 
INSTITUTO BRASILEIRO DE GEOGRAFIA E ESTATÍSTICA. Produto Interno Bruto dos Municípios de 1999-2011. Brasília, DF. Avalaible in: <http://www.sidra. ibge.gov.br/bda/pesquisas/PIBMun/default.asp>. Access in: Set. 11 2014c.

INSTITUTO BRASILEIRO DE GEOGRAFIA E ESTATÍSTICA. Redes e fluxos do território: gestão do território. Rio de Janeiro, 2014d.

KONRAD, J.; SILVA, C. A. da. Agricultura familiar no Oeste catarinense: da colônia à integração. In: ENCONTRO NACIONAL DE GEOGRAFIA AGRÁRIA: TERRITÓRIOS EM DISPUTA - OS DESAFIOS DA GEOGRAFIA AGRÁRIA NAS CONTRADIÇÕES DO DESENVOLVIMENTO BRASILEIRO, 21., 2012, Uberlândia. Proceedings... Uberlândia, 2012.

MIOR, L. C. Agricultores familiares, agroindústrias e redes de desenvolvimento rural. Chapecó: Argos, 2005.

REIS, J. Uma epistemologia do território. Lisboa: Faculdade de Economia da Universidade de Lisboa, 2002.

SANTOS, M.; SILVEIRA, M. L. O Brasil: território e sociedade no final do século XX. 9. ed. 2006.

TESTA, V. M. et al. O desenvolvimento sustentável do Oeste catarinense: proposta para discussão. Florianópolis: EPAGRI, 1996.

VERGARA, S. C. Projetos e relatórios de pesquisa em administração. 13. ed. São Paulo: Atlas, 2011.

WERLANG, A. A colonização do Oeste catarinense. Chapecó: Argos, 2002. 
How to mention this paper:

\section{ABNT:}

BERNARDY, Rógis Juarez. Regional analysis based on the demographic and economic variation of the association of the municipalities of Western Santa Catarina. RACE, Revista de Administração, Contabilidade e Economia, Joaçaba: Ed. Unoesc, v. 15, i. 2, p. 395-418, May/Aug. 2016. Avalaible in: <http://editora.unoesc. edu.br/index.php/race>. Access in: month/day/year.

\section{APA:}

Bernardy, R. J., Karnopp, E., Etgs, V. E., \& Vogt, O. P. (2016). Regional analysis based on the demographic and economic variation of the association of the municipalities of Western Santa Catarina. RACE, Revista de Administração, Contabilidade e Economia, 15(2), 395-3418. Retrieved from http://editora.unoesc.edu.br/index. php/race 